\title{
Meta analysis: Relationship of recapping actions and years of service with the incidence of needle stick injury in health workers at health facilities
}

\author{
Muhammad Lutfi Yunus ${ }^{1}$, Husaini $^{2}$, Eko Suhartono ${ }^{3}$, Erida Wydiamala ${ }^{4}$, Lenie Marlinae ${ }^{5}$ \\ ${ }^{1}$ First Aid Clinic of PT. Pelindo Husada Citra Banjarmasin, Faculty of Medicine Lambung Mangkurat University, \\ Banjarmasin, Indonesia \\ 2, 3 Master of Public Health Science, Faculty of Medicine Lambung Mangkurat University, Banjarmasin, Indonesia \\ ${ }^{4}$ Faculty of Medicine Lambung Mangkurat University, Banjarmasin, Indonesia \\ ${ }^{5}$ School of Public Health, Faculty of Medicine Lambung Mangkurat University, Banjarmasin, Indonesia
}

\section{Keywords}

Needlestick

Injury

Recapping

Nurse

Hospital

Received:11 January 2021

Accepted: 10 May 2021

Published: 20 September 2021

\begin{abstract}
Health workers in providing services have the potential risk of needle stick injuries or other sharp objects, these can carry blood pathogens such as hepatitis B virus (HBV), hepatitis C virus (HCV), HIV and twenty more other pathogens, which have an impact on infection where the chance of contracting Hepatitis B, Hepatitis C and HIV infection. According to the World Health Organization, globally, about 3 million of the 35 million health care workers receive exposure to blood-borne pathogens each year. A total of 2,000,000 health workers of whom infected the Hepatitis B virus, 900,000 infected the Hepatitis C virus (HCV), and another 170,000 were infected with the Human Immunodeficiency Virus (HIV). Several studies have shown that recapping and years of service are associated with the incidence of needle sticks in health facilities. To examine studies that explain the relationship between recapping actions and years of service for health workers with the incidence of needle sticks injury in health facilities. This study used an observational study with a cross sectional design. Sources of data obtained from secondary data through Online. Data collection procedures using databases include Pubmed, Google Scholar and Garuda Portal with a range of 2016-2020. Analyzed using the Revman 5.3 application. Results Of the 33 studies obtained according to the inclusion and exclusion criteria, 14 studies were obtained which could be continued to the analysis stage using the Revman 5.3 Application. The recapping action variable uses 10 studies and years of service using 9 studies. The results of data analysis showed that there was a relationship between recapping and the incidence of needle sticks with a $p$-value $=0.00001$ and a Pooled odds ratio value of 2.71 (95\% CI 2.32, 3.16) and the data results showed a relationship between years of service and the incidence of needle stick injury with $p=0.008$ and pooled odds ratio $1.82(95 \% \mathrm{CI} 1.17,2.85)$. There is a relationship between recapping actions and years of service for health personnel with the incidence of needle sticks injury in health facilities.
\end{abstract}

(c) 2021 The Author(s). Published by TAF Publishing.

\section{INTRODUCTION}

Data according to the World Health Organization globally states that about 3 million of the 35 million health care workers receive exposure to blood-borne pathogens each year [1]. A total of 2,000,000 health workers of whom infected the Hepatitis B virus, 900,000 infected the HCV, and 170,000 others were infected with the Human Immunodeficiency Virus [2,3]. Work accidents due to sharp objects or so-called Needle Stick Injuries (NSI) are a serious problem in the health sector, as well as a work safety issue that must be faced by health workers in general. Health workers in providing services have the potential risk of needle stick wounds or other sharp objects, these can carry blood pathogens such as hepatitis B virus (HBV), HCV, HIV and twenty more other pathogens, which have an impact on infection where the chance of contracting Hepatitis B, Hepati-

\footnotetext{
* corresponding author: Muhammad Lutfi Yunus

†email: lutfiy28071995@gmail.com
} 
tis $\mathrm{C}$ and HIV infection $[4,5]$.

The causes of Needlestick Injury incidence by nurses include giving injections, taking blood, sewing wounds, when closing syringes and when disposing of needles [6]. The Center for Occupational Health and Safety [7] says that there are several things that cause the occurrence of Needlestick Injury in hospitals, namely equipment design, standard operating procedures, working conditions, years of work, and recapping actions.

From the results of a literature search on the relationship between recapping and years of service with the incidence of needle sticks injury, 14 articles were found, from 9 studies related to years of service, it was found that $67 \%$ of research journal articles explained that there was a relationship between years of service and the incidence of needle sticks injury and the rest stated no related. Meanwhile, 10 studies related to the relationship between recapping actions, it was found that $80 \%$ of them stated that there was a relationship and $20 \%$ of research journal articles stated that there was no relationship [8]. Based on the facts of the results of the study, the years of service and the recapping action with the incidence of needle sticks injury are still an interesting topic of discussion to be studied. This is due to the findings of differences in research results for this matter [9]. Thus, in this study, will be studied the relationship between years of service and recapping actions with the incidence of needle sticks injury using a meta-analysis [10].

\section{METHOD}

This study used an observational study with a cross sectional design. Sources of data obtained from secondary data through Online. Data collection procedures using databases include Pubmed, Google Scholar and Garuda Portal with a range of year from 2016-2020. Analyzed using the Revman 5.3 application.

\section{RESULTS AND DISCUSSION}

There are several studies that have analyzed the act of recapping and years of service but the results are contradictory. For this reason, statistical analysis was carried out using meta-analysis to prove the quality of each study so that new data that was quantitative in nature and more accurate conclusions could be drawn.

\section{A. The Relationship of Recapping Actions with Inci- dents of Needlestick Injury}

The results of the meta-analysis for studies that assessed the relationship between recapping actions and the incidence of needle sticks injury in health facilities are shown in Figure 1 [11].

\begin{tabular}{|c|c|c|c|c|c|c|c|}
\hline Study or Subgroup & log[Odds Ratio] & SE & Weight & $\begin{array}{l}\text { Odds Ratio } \\
\text { N, Fixed, } 95 \% \mathrm{Cl}\end{array}$ & \multicolumn{3}{|c|}{$\begin{array}{c}\text { Odds Ratio } \\
\mathrm{N} \text {, Fixed, } 95 \% \mathrm{Cl}\end{array}$} \\
\hline Abate, 2020 & 1.3838 & 0.3037 & $6.7 \%$ & $3.99[2.20,7.24]$ & & & $\longrightarrow$ \\
\hline Aldakhil, dkk 2019 & 0.4637 & 0.4259 & $3.4 \%$ & $1.59[0.69,3.66]$ & & & \\
\hline Asse, dkk 2020 & 0.967 & 0.3254 & $5.8 \%$ & $2.63[1.39,4.98]$ & & & \\
\hline Dilie, dkk 2020 & 2.0149 & 0.4036 & $3.8 \%$ & $7.50[3.40,16.54]$ & & & \\
\hline Gabr,dkk 2018 & 0.967 & 0.11 & $51.1 \%$ & $2.63[2.12,3.26]$ & & & +7 \\
\hline Getie, dkk 2020 & 1.3558 & 0.4313 & $3.3 \%$ & $3.88[1.67,9.04]$ & & & \\
\hline Kaweti, 2016 & 0.7655 & 0.245 & $10.3 \%$ & $2.15[1,33,3.48]$ & & & 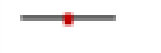 \\
\hline Liyew, dkk 2020 & 0.5766 & 0.2816 & $7.8 \%$ & $1.78[1.02,3.09]$ & & & \\
\hline Mekonnen, dkk 2018 & 0.47 & 0.5248 & $2.2 \%$ & $1.60[0.57,4.48]$ & & & \\
\hline Weldesamuel, dkk 2019 & 1.4646 & 0.3369 & $5.4 \%$ & $4.33[2.24,8.37]$ & & & \\
\hline Total $(95 \% \mathrm{Cl})$ & & & $100.0 \%$ & $2.71[2.32,3.16]$ & & & \\
\hline $\begin{array}{l}\text { Heterogeneity } \mathrm{Ch}^{2}=163 \\
\text { Test for overall effect } \mathrm{Z}=\end{array}$ & $\begin{array}{l}B, d f=9(P=0.06) ; \\
2.65(P<0.00001)\end{array}$ & $P^{2}=45 \%$ & & & 0.05 & $\begin{array}{l}0.2 \\
\text { No recapping }\end{array}$ & Recapping \\
\hline
\end{tabular}

Fig. 1. Analysis of the combined forest plot recapping relationship with the incidence of needlestick injury in health facilities 
Based on Figure 2, the combined study states that there is a relationship between recapping actions on health workers and the incidence of needle sticks injury with a $p$-value $<0.05$, namely $p=0.00001$ and an adjusted odds ratio value of 2.71 (95\% CI 2.32-3.16). Recapping action has a risk of 2.71 times compared to not doing recapping significantly [12]. The results of the heterogeneity test showed that the research variation was moderately heterogeneous, with a $p$-value greater than 0.05 in the heterogeneity test, namely $\mathrm{p}=0.06$ and the variation value between studies ( $\mathrm{I} 2=45 \%$ $(<50 \%)$ so that the fixed effect model analysis used. It can be concluded that recapping increases the risk or tends to be 2.71 times more than the non-recapping action[13].

It is possible that health workers who are still doing recapping do not understand the dangers of recapping needles, or have understood but have not abandoned the habit. Therefore, it is necessary to socialize the dangers of recapping needles and give a warning if they see that there are still health workers who are still doing it [14].
Based on the analysis of 10 articles, it was found that there was a significant relationship between recapping and the incidence of needle sticks injury in health facilities. The results of this study are in line with research conducted by Ifadah \& Susanti, 2018 The results of statistical tests obtained $p$-value $=0.003$ it can be concluded that there is a difference in the proportion between nurses who do recapping neddles and do not recapping neddles who are at risk for Needle stick injury (NSI) (there is a relationship between significant difference between recapping neddles and Needle stick injury) [15]. From the results of the analysis, the value of $\mathrm{OR}=4.152$, it means that nurses who do recapping neddles have a chance of 4.152 times to get needle stick injury compared to nurses who do not recapping neddles.

\section{B. The Relationship Between the Years of Service and the Incidence of Needle Sticks}

The results of the meta-analysis for studies assessing the relationship between years of service and the incidence of needle stick injuries are shown in Figure 22 [16].
Odds Ratio Odds Ratio

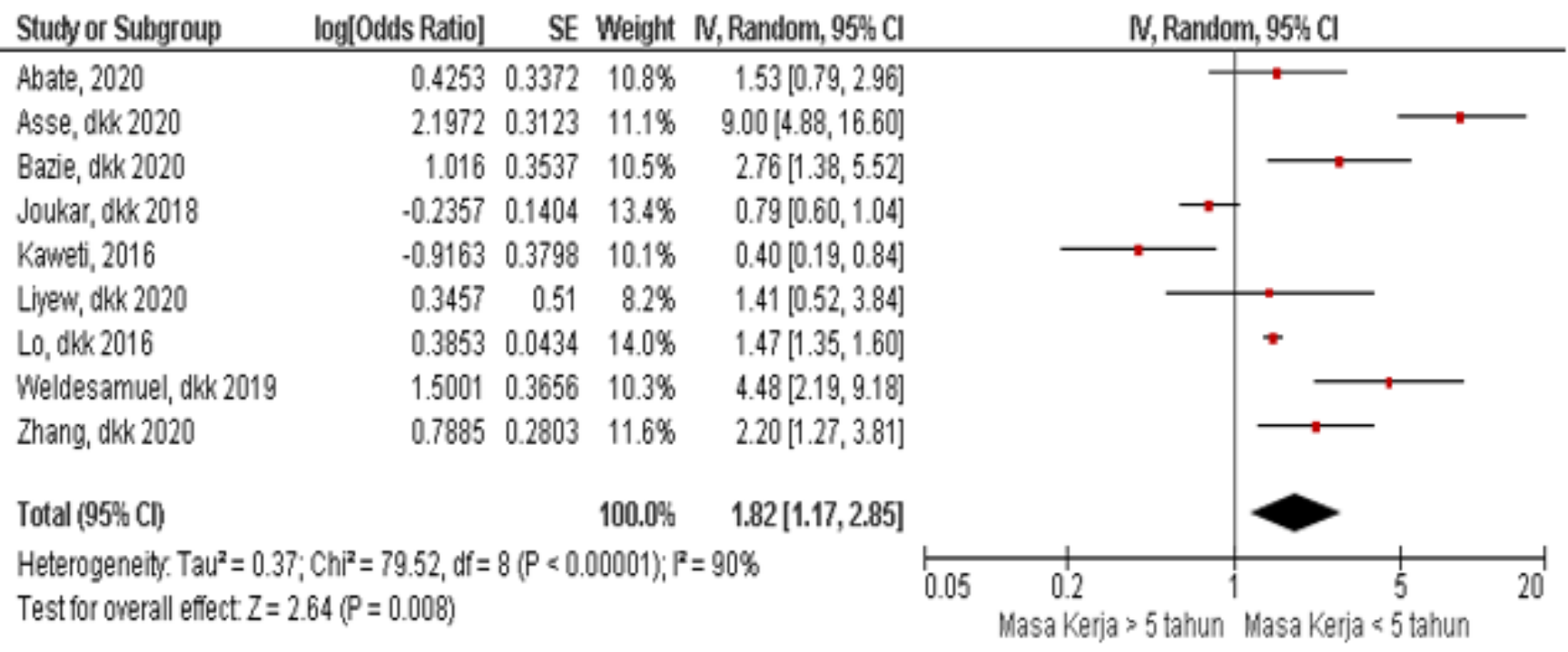

Fig. 2. Forest plot analysis of the relationship between years of service and incidence of needle sticks injury in health facilities

Based on Figure 2. it shows that there is a relationship between years of service for health workers and the incidence of needle sticks with a $p$-value $<0.05$, namely $p=0.008$ and an adjusted odds ratio value of 1.82 (95\% CI 1.17-2.85) years of service $<5$ years has a risk of 1.82 times compared to years of service $>5$ years significantly. The results of the heterogeneity test showed that the variation of the research was very high heterogeneous, with a $p$-value of 0.05 less than in the heterogeneity test, namely $p=0.00001$ and the value of variation between studies I $2=90 \%$ ( $>50 \%)$ so that the random effects analysis model was used. It can be concluded that the years of service $<5$ years increases the risk or tends to be 1.82 times more than the years of service $>5$ years [17].

The years of service is a period of time or the length of time workers work in a place. Fewer years of service for healthcare workers were more likely to experience needling than those with more years of service. The reason is that workers 
who lack experience when in stressful situations at work, they do not receive training do not know how to manage used sharps, and they may even care less about injuries than workers with longer experience [18]. According to Reese [19] the years of service also determines a person's performance in carrying out tasks. The longer a person's years of service, also give higher productivity. The longer a person years of service the more skilled and faster he completes a task.

The assumption of researchers in carrying out work, the more years of service someone will increase productivity and show better behavior at work in this case preventing the occurrence of NSI.

\section{CONCLUSION AND IMPLICATIONS}

The results of meta-analysis and synthesis of data from previous research articles that match the inclusion criteria, it can be concluded that there is a relationship between recapping actions and years of service for health workers with the incidence of needle sticks in health facilities. Recommendations based on the results of this study arrangement makes policies for all health workers to carry out their duties according to standard operating procedures that have been made regarding safety in the workplace in order to prevent the risk of infection or transmission of infectious diseases through needles.

\section{REFERENCES}

[1] Abadiga M, Mosisa G, Abate Y. Magnitude of needlestick and sharp Injury and Its associated factors among nurses working at health institutions in Western Ethiopia, 2020. Risk Management and Healthcare Policy. 2020;13:15-89. doi: https://doi.org/10.2147/RMHP.S254641.

[2] Weldesamuel E, Gebreyesus H, Beyene B, Teweldemedhin M, Welegebriel Z, Tetemke D. Assessment of needle stick and sharp injuries among health care workers in central zone of Tigray, Northern Ethiopia. BMC Research Notes. 2019;12(1):1-6. doi: https://doi.org/10.1186/s13104-019-4683-4.

[3] Bhatt M. The 'thought model' of spirituality to solve conflicts in training and education of spiritual health in modern public healthcare systems. International Journal of Health and Medical Sciences. 2019;5(1):29-34. doi: https://dx.doi. org/10.20469/ijhms.5.30004-1.

[4] Zhang Y, Liu L, Cai K, Zhang L, Liu L, Zhou X, et al. Cross-sectional study assessing the risk of needlestick injury from an insulin pen among nursing care providers. Journal of International Medical Research. 2020;48(10):4-10. doi: https: //doi.org/10.1177/0300060520965400.

[5] Szakaly Z, Peto K. Health behaviour, behaviour change and personalised diet: The concept of lifelong health. Journal of Advances in Health and Medical Sciences. 2018;4(2):43-52. doi: https://doi.org/10.20474/jahms4.2.2.

[6] Meilawati I, Prapancha Y, Wiyono T. Factors Associated with the Incidence of needlestick wounds in Nurses at Bhayangkara Brimob Hospital in 2018. Jurnal Bidang Ilmu Kesehatan. 2019;9(1):24-36. doi: https://doi.org/10. 52643/jbik.v9i1.343.

[7] Getie A, Wondmieneh A, Tesfaw G. The prevalence of needlesticks and sharp injuries, and the associated factors among midwives and nurses in North Wollo Zone Public Hospitals, North East Ethiopia: An institution-based cross-sectional study. Drug, Healthcare and Patient Safety. 2020;12:187-197. doi: https://doi.org/10.2147/DHPS.S273669.

[8] Lo WY, Chiou ST, Huang N, Chien LY. Long work hours and chronic insomnia are associated with needlestick and sharps injuries among hospital nurses in Taiwan: A national survey. International Journal of Nursing Studies. 2016;64:130-136. doi: https://doi.org/10.1016/j.ijnurstu.2016.10.007.

[9] Kebede A, Gerensea H. Prevalence of needle stick injury and its associated factors among nurses working in public hospitals of Dessie town, Northeast Ethiopia, 2016. BMC Research Notes. 2018;11(1):1-6. doi: https://doi.org/10. 1186/s13104-018-3529-9.

[10] Joukar F, Mansour-Ghanaei F, Naghipour M, Asgharnezhad M. Needlestick injuries among healthcare workers: Why they do not report their incidence? Iranian Journal of Nursing and Midwifery Research. 2018;23(5):382-397. doi: https://doi.org/10.4103/ijnmr.IJNMR_74_17.

[11] Higgins JP, Thompson SG, Deeks JJ, Altman DG. Measuring inconsistency in meta-analyses. Bmj. 2003;327(7414):557-560. doi: https://doi.org/10.1136/bmj.327.7414.557.

[12] Al Jarallah AM, Ahmed AS, et al. Risk management approach of needle stick and sharp injuries among nurses, Saudi Arabia: An interventional study. Journal of The Arab Society for Medical Research. 2016;11(2):50-60. 
[13] Aderaw Z. Assessment on magnitude of needle stick and sharp injuries and associated factors among health care workers in East Gojjam zone health institutions, Amahara Regional State, Ethiopia. Global Journal of Medical Research. 2013;13(3):41-49.

[14] Dilie A, Amare D, Gualu T. Occupational exposure to needle stick and sharp injuries and associated factors among health care workers in Awi Zone, Amhara Regional State, Northwest Ethiopia, 2016. Journal of Environmental and Public Health. 2017;2(6):56-65.

[15] Mekonnen R, Yosef H, Teklegiorgis K, Tesfaye F, Dagne I. Magnitude and impact of occupational related needle stick and sharp injuries and associated factors among health care workers in Dire Dawa, Eastern Ethiopia. Med Saf Glob Health. 2018;7(1):2574-0407. doi: https://doi.org/10.4172/2574-0407.1000141.

[16] Liyew B, Sultan M, Michael M, Tilahun AD, Kassew T. Magnitude and determinants of needlestick and sharp injuries among nurses working in tikur anbessa specialized hospital, Addis Ababa, Ethiopia. BioMed Research International. 2020;20(6):45-60.

[17] Gabr HM, El-Badry AS, Younis FE. Risk factors associated with needlestick injuries among health care workers in Menoufia governorate, Egypt. The International Journal of Occupational and Environmental Medicine. 2018;9(2):63-80. doi: https://doi.org/10.15171/ijoem.2018.1156.

[18] Walle L, Abebe E, Tsegaye M, Franco H, Birhanu D, Azage M. Factors associated with needle stick and sharp injuries among healthcare workers in Felege Hiwot Referral Hospital, Bahir Dar, Northwest Ethiopia: Facility based crosssectional survey. International Journal of Infection Control. 2013;9(4):56-70. doi: https://doi.org/10.3396/ijic.v9i4. 11709.

[19] Reese CD. Industrial safety and health for administrative services. New York, NY: CRC Press; 2008. 